\title{
Constitutional Rights of the Corporate Person
}

The corporation is the dominant and, some would argue, the definitive institution of modern capitalist economies. Because it is recognized as a legal person, basic decisions about the corporation often come in the form of judicial pronouncements as to the nature of the corporate party seeking redress or defending its actions.

Three views of the corporate person have dominated Anglo-American jurisprudence. Each reduces corporate personality to the interests of a single party, thereby excluding or delegitimizing the interests of all others. This Note argues that the corporate person should instead be seen as the totality of legally specified powers and duties of agents toward a diverse set of interested parties. This approach generates a method for analyzing the rights and responsibilities of corporate parties that differs radically from the methods associated with the several views heretofore dominant. The suggested approach rejects the notion that constitutional rights flow directly from the nature of the corporate person, as they might from the nature of natural persons; the ascription or denial of these rights to corporate parties represents instead a legal ordering of the rights of those persons whose interaction through agents constitutes the corporate whole.

\section{The Corporate Person as a Bearer of Rights and Duties}

The presence of corporate parties before the courts is today a commonplace in Anglo-American legal systems, even though the corporation has only recently been recognized as a juristic person ${ }^{1}$ capable of bearing rights and duties. ${ }^{2}$ As common as its presence may be, the legal nature of the corporate person has defied simple analysis. ${ }^{3}$ As a result, courts have

1. A juristic person is a being who can be the bearer of a right and consequently claim standing in a court. Not until Boethius's definition of a persona as a rational being (naturae rationabilis individua substantia) were non-legal, metaphysical characteristics ascribed to personae. See French, The Corporation as a Moral Person, 16 AM. PHIL. Q. 207, 208 (1979).

2. Roman law, for instance, did not generally "know the concept of an association of individuals having a legal personality (corpus)." E. BADIAN, PUBLICANS AND SINNERS: PRIVATE ENTERPRISE IN THE SERVICE OF THE ROMAN REPUBLIC 69 (1976). The concept was first generalized in ecclesiastical courts and then imported into English law. See infra note 23. The legal capacity of the corporate person was greatly restricted until well into the nineteenth century. See infra p. 1647.

3. The result has been a sea of literature. Major contributions in the twentieth century include: $F$. Hallis, Corporate Personality (1978); A. NEKaM, THE Personality CONCEPTION OF The LEGAL ENTITY (1938); O. VON GIERKE, POLITICAL THEORIES OF THE MIDDLE AGES (1938); Dewey, The Historic Background of Corporate Legal Personality, 35 Yale L.J. 283 (1926); Hart, Definition and Theory in Jurisprudence, 70 LAW Q. REV. 37 (1954); Laski, The Personality of Corporations, 29 HARV. L. REV. 404 (1916). 
been unable to define corporate constitutional rights in a consistent manner.

\section{A. Traditional Models of Corporate Personality: First National Bank v. Bellotti}

The several models of corporate personality at work in Anglo-American jurisprudence can perhaps best be seen in First National Bank v. Bellotti, ${ }^{4}$ a decision that settled in fundamental ways the extent to which the First Amendment applies to corporate speech. The disparate opinions filed in the case appear to rest on different visions of the protections the Constitution affords political expression; they also belie, however, fundamentally different conceptions of corporate existence. Thus, Bellotti provides a convenient introduction to the several theories which have dominated judicial and academic discussion of the corporate person.

Bellotti involved a constitutional challenge to a Massachusetts statute that prohibited corporate expenditures designed to influence public referenda on matters not affecting corporate business or assets. ${ }^{5}$ In denying that corporate First Amendment rights are coextensive with those of natural persons, the Supreme Judicial Gourt of Massachusetts concluded that corporations can claim only those constitutional guarantees that flow from the protection afforded property by the Fourteenth Amendment. ${ }^{6}$ The

4. First Nat'l Bank v. Attorney Gen., 371 Mass. 773, 359 N.E.2d 1262 (1977), rev'd sub nom. First Nat'l Bank v. Bellotti, 435 U.S. 765 (1978).

Bellott $i$ has spawned a great deal of comment. Legal analyses of the case generally fall into either of two categories. The first focuses on how the arguments advanced in the various opinions comport with traditional First Amendment analysis. See, e.g., Brudney, Business Corporations and Stockholder Rights Under the First Amendment, 91 Yale L.J. 235 (1981); Patten \& Bartlett, Corporate "Persons" and Freedom of Speech: The Political Impact of Legal Mythology, 1981 WIS. L. REV. 494. The second speculates on how Bellotti will affect future challenges to laws restricting corporate participation in political affairs. See, e.g., Kiley, PACing the Burger Court: The Corporate Right to Speak and the Public Right to Hear after First National Bank v. Bellotti, 22 ARIZ. L. REV. 427 (1980); Schaefer, The First Amendment, Media Conglomerates and "Business" Corporations: Can Corporations Safely Involve Themselves in the Political Process?, 55 ST. JOHN'S L. REV. 1 (1980).

One theme has been largely ignored by this literature: how the various views of the corporate person underlying the several opinions filed in Bellotti determine the substantive conclusions the opinions reach. One article does touch on the models of the corporate person latent in Bellotti and other relevant high court decisions. See O'Kelley, The Constitutional Rights of Corporations Revisited: Social and Political Expression and the Corporation after First National Bank v. Bellotti, 67 GEo. L.J. 1347 (1979); infra note 55.

5. The statute provided in relevant part:

No corporation carrying on the business of a bank, . . . no business corporation incorporated under the laws of or doing business in the commonwealth . . . shall directly or indirectly, pay, expend or contribute . . . any money or other valuable thing for the purpose of . . . influencing or affecting the vote on any question submitted to the voters, other than one materially affecting any one of the property, business or assets of the corporation.

Mass. GEN. LAwS ANN. ch. 55, 88 (West Supp. 1981).

6. First Nat'l Bank v. Attorney Gen., 371 Mass. 773, 783, 359 N.E.2d 1262, 1269 (1977), rev'd sub nom. First Nat'l Bank v. Bellotti, 435 U.S. 765 (1978). Since the turn of the century, business corporations have consistently been deemed persons for the purposes of the due process and equal 
court apparently understood corporations as creatures of purely economic interest, sustained by shareholders who must be protected from the illegitimate use of their capital. ${ }^{7}$ It saw the Massachusetts statute as a rational and constitutionally acceptable attempt to provide such protection.

The United States Supreme Court reversed the decision of the state tribunal, holding that the statute violated the First Amendment. Writing for the majority, Justice Powell asked whether "the corporate identity of the speaker" could deprive "this proposed speech of what would otherwise be its clear entitlement to protection." $\mathrm{He}$ concluded that legislatures are "constitutionally disqualified from dictating the subjects about which persons may speak and the speakers who may address a public issue." deprive the polity of the corporation's views on any matter would impermissibly limit the stock of information available to the public. ${ }^{10}$

In a strongly worded dissent, Justice White challenged the way the principal issue had been framed. He asked instead "whether a State may prevent corporate management from using the corporate treasury to propagate views having no connection with the corporate business."11 The interests of the corporate person, it would seem, are subordinate to those of the sovereign; corporate rights are privileges that should be tailored to suit the commonweal. If the public good is not served by unrestricted corporate involvement in the political process, legislatures are free to limit the body corporate to the activity for which it was called into being: business. "The State," Justice White concluded, "need not permit its own creation to consume it."12

\section{B. Constitutional Rights of the Corporate Person}

Bellotti is by no means the only case in which the resolution of a constitutional issue depends, at least in part, on the court's view of the corporate

protection guarantees of the Fourteenth Amendment. See infra note 13.

7. See First Nat'l Bank v. Attorney Gen., 371 Mass. 773, 793-94, 359 N.E.2d 1262, 1275 (1977) (existence of shareholders distinguishes corporations from other "persons similarly circumstanced"), rev'd sub nom. First Nat'l Bank v. Bellotti, 435 U.S. 765 (1978).

8. First Nat'l Bank v. Bellotti, 435 U.S. 765, 778 (1978). Justice Powell's formulation of the key question posed by Bellotti shows how difficult it is, despite his assertions to the contrary, id. at 776, to settle the matter without referring to and analyzing the identity of the speaker. See infra p. 1651.

Chief Justice Burger and Justices Stewart, Blackmun, and Stevens joined in Justice Powell's opinion. The Chief Justice also filed a concurring opinion. Justice White filed a dissenting opinion in which Justices Brennan and Marshall joined. Justice Rehnquist filed a separate dissent. This Note does not examine the concurrence filed by the Chief Justice, which looks at the effect of the Massachusetts statute on corporate media. Nor does the Note examine Justice Rehnquist's dissent except as it bears on the dissent filed by Justice White; see infra note 26.

9. 435 U.S. at 784-85.

10. Id. at 783; see infra p. 1651 (discussing corporate contributions to the stock of public information).

11. 435 U.S. at 803 (White, J., dissenting).

12. Id. at 809 (White, J., dissenting); see infra p. 1646 (discussing Justice White's dissent). 
person. The decision that corporate political speech is protected by the First Amendment is part of a patchwork of holdings defining corporate constitutional rights.

The corporate person is protected by the due process and equal protection clauses of the Fourteenth Amendment, ${ }^{13}$ but not by the other provisions of that Amendment. ${ }^{14}$ Though a corporation is not a citizen, ${ }^{16}$ it may sue in federal courts under diversity jurisdiction. ${ }^{16}$ The corporation is secure from unreasonable searches and seizures ${ }^{17}$ and from the risks of double jeopardy, ${ }^{18}$ but it may not claim a right against self-incrimination. ${ }^{10}$ The corporation may be deprived of privileges and immunities states normally accord their own citizens, ${ }^{20}$ but no government-state or federal-may impair the contract implicit in the corporate charter. ${ }^{21}$

There is no way to bring unity to these many decisions, for they rest on radically different conceptions of the person whose rights and duties re-

13. See Minneapolis \& St. L. Ry. v. Beckwith, 129 U.S. 26 (1889) (due process); Santa Clara County v. Southern Pac. R.R., 118 U.S. 394 (1886) (equal protection). In a series of decisions in the late nineteenth and early twentieth centuries, the Supreme Court infused the due process clause with substantive content, thereby shielding business corporations from state supervision. See, e.g., Allgeyer v. Louisiana, 165 U.S. 578 (1897) (due process protects liberty of contract); Reagan v. Farmers' Loan \& Trust Co., 154 U.S. 362 (1893) (due process clause subjects state economic regulatory legislation to "reasonableness test"). In general, the line of cases explaining the corporate right to equal protection and due process has made every act of state and local governments adversely touching the rights of corporate persons subject to review by the Supreme Court. See infra note 35.

14. See Northwestern Nat'l Life Ins. Co. v. Riggs, 203 U.S. 243 (1906) (liberty guaranteed by Fourteenth Amendment extends only to natural persons and not to corporations). But see First Nat'l Bank v. Bellotti, 435 U.S. 765, 778-79 (1978) (rejecting as "artificial mode of analysis" lower court's argument that corporations cannot claim Fourteenth Amendment's protection of liberty).

15. See Bank of the United States v. Deveaux, 9 U.S. (5 Cranch) 61, 86 (1809) (corporations "as such" are not persons as term is used in Article III and Judiciary Act of 1789). But see Louisville, C. \& C. R.R. Co. v. Letson, 43 U.S. (2 How.) 497, 558 (1844) ("[A] corporation created by . . . a state, is to be deemed to all intents and purposes as a person, although an artificial person, . . . capable of being treated as a citizen of that state, as much as a natural person.").

16. See Bank of the United States v. Deveaux, 9 U.S. (5 Cranch) 61, 91 (1809) (jurisdiction is determined by the "real persons" (that is, shareholders) coming to court under the corporate name).

17. See Hale v. Henkel, 201 U.S. 43 (1906) (subpoena for production of corporate records so broad as to constitute unreasonable search and seizure in violation of Fourth Amendment); infra note 57 (discussing Hale).

18. See United States v. Martin Linen Supply Co., 430 U.S. 564 (1977) (acquittal of corporation in accordance with FED. R. CRIM. P. 29(c) is not appealable because of Fifth Amendment protection against double jeopardy).

19. See Hale v. Henkel, 201 U.S. 43 (1906) (subpoena for testimony of corporate officer upheld against claim of corporate Fifth Amendment privilege).

20. See Bank of Augusta v. Earle, 38 U.S. (13 Pet.) 519 (1839) (because corporations are not citizens within the meaning of the privileges and immunities clause of Article IV, a state is not required to give extraterritorial effect to corporate charters granted by another state). Subsequent decisions vitiated much of the force of the Augusta holding insofar as it limited corporate rights to do business in states other than the state of incorporation. See infra notes 32, 57.

21. See Trustees of Dartmouth College v. Woodward, 17 U.S. (4 Wheat.) 518 (1819) (state revocation of corporate charter violates contracts clause of Article I). Justice Story, who wrote a concurring opinion in the Dartmouth case, saw the decision as raising an "impregnable barrier" around corporations, thus rendering solid and inviolable the "commercial institutions of the country." $2 \mathrm{~J}$. STORY, COMMENTARIES ON THE CONSTITUTION OF THE UNITED STATES $§ 1395$ (Boston 1833). See infra notes 29,57 . 
ceive judicial definition. The several views of corporate personality reflected in these cases can all be found in Bellotti. That case can thus be used to illustrate the traditional models and to show how the choice of a paradigm largely determines the scope of corporate rights.

\section{Traditional Explanations of Corporate Personality}

To understand the action taken by First National Bank in Bellotti, a suit brought by a corporation in its own name for a declaration of rights, one would have to examine the nature of the person petitioning the court. There has been no dearth of speculation as to the kind of person attorneys for the body corporate represent, though the many theories advanced to explain the corporate person can be reduced to three paradigms that have successively dominated judicial opinion. The rise of a new theory usually does not signify the complete disappearance of the view that has been superseded. Earlier views continue to exist as part of the judicial common sense, ready to be resurrected if the dominant view fails to guide decisionmaking in peculiar circumstances or leads to unpalatable consequences.

\section{A. Fiction Theory}

The earliest complete view of corporate personality, the fiction theory, explains the presence of corporate parties before a court by referring to a political event: the decision of the sovereign to create a social unit by grant of legal status. ${ }^{22}$ The corporation thus exists as a person only because it is recognized by the law, and it is granted standing in the court only because it has been brought into being by the state. ${ }^{23}$

Under this view, the corporate entity can do only that which the sovereign allows. Of its own power, the corporation "does no act, speaks no word, thinks no thoughts."24 This limiting vision of the powers of the

22. "Ten men do not become in fact one person because they associate themselves together for one end any more than two horses become one animal when they draw the same cart." J. SALMOND, JURISPRUDENCE 350 (1902), quoted in Laski, supra note 3, at 406. An act of the legislature is necessary to become one in the eyes of the law. Those who, "without the sanction of the legislature, presume to act as a corporation, are guilty of a contempt of the King, by usurping on his prerogative." Duvergier v. Fellows, 5 Bing. 248, 268, 130 Eng. Rep. 1056, 1064 (C.P. 1828), affd, 34 Rev. Rep. 578 (K.B. 1830).

23. Thus, Coke distinguishes "persons incorporate or politique created by the policy of man" and "persons natural created by God." The former-also known as corporations aggregate-are "invisible, immortal, and rest only in the intendment and consideration of the law." Quoted in 2 J. DAVIS, CORPORATIONS 214 (1905). The doctrine that corporations are fictions was first applied to ecclesiastical bodies. See Dewey, supra note 3, at 665 (a collegium, universitas, or capitulum, as incorporeal and soulless rei fictae, could not be punished or be guilty of a delict).

24. Maitland, Introduction to $O$. VON GIERKE, supra, note 3, at xxi. The several meanings given to the term fiction theory in the literature can be distinguished along ontological and political lines. All advocates of this view agree that the law calls forth the corporation out of nothing, that is, no extra-legal entity exists prior to the sovereign's act. Dispute arises, however, as to whether the sover- 
corporate person filtered through the common law tradition to govern the legal status of corporations in the English colonies and the early United States. ${ }^{25}$

Though the fiction theory has long since fallen from dominance, judicial decisions regarding the powers and responsibilities of corporations often appear, even today, to rest on political assumptions that are reasonable only in the context of a fiction-like view. In Bellotti, for instance, when Justice White refers to the First National Bank as a creature of the state, he implies that the very existence of the corporation is the result of an extraordinary political act that should be tailored to the needs of the commonweal. ${ }^{26}$ If the grant bestowing life to the corporation does not serve

eign creates some thing which then acquires a life of its own. Compare Coke, quoted in J. DAvis, supra note 23, at 214 (corporation exists only in the "intendment and consideration of the law") with Machen, Corporate Personality, 24 HARV. L. REV. 253, 257 (1910) ("If a corporation is 'created,' it is real, and therefore cannot be a purely fictitious body having no existence except in the legal imagination."). This Note adopts the more traditional view: to say that corporate personality is a fiction is to claim that no extra-legal ens underlies these non-natural, juristic persons; they exist only according to the "intendment" of the state. Quasi-fictional views, which assert that the act of the sovereign creates a being with a life of its own, are treated as instances of realism. See infra pp. 1649-51.

Fiction theories can also be distinguished along political lines. A strong version of the theory (sometimes referred to as the "concession" view) maintains that the centrality of the sovereign's act to the corporation's existence makes all corporate acts in effect acts of the government, corporate officers being ultimately accountable to the state. See R. WINTER, GOVERNMENT AND THE CORPORATION 1 (1978). This version of the fiction view makes most sense if restricted to that era when incorporation occurred only through special charter, that is, only through a royal grant of exclusive monopoly. As the term is used in this Note, the fiction theory does hold the state ultimately responsible for overseeing the exercise of corporate power, but only in setting the bounds of that power in the corporate charter. Any activity beyond those bounds is ultra vires.

25. Thus, well into the nineteenth century, legislatures granted charters of incorporation tailored to specific social needs. Because the powers conferred by charter were deemed special privileges granted by the sovereign, charters were strictly construed by the courts. See J. HURST, THE LEGITIMACY OF THE BUSINESS CORPORATION IN THE LAW OF THE UNITED STATES 13-57 (1970). The state frequently challenged unauthorized acts of corporations through a quo warranto proceeding, the same action by which allegedly wrongful assertions of public powers were tested. D. VAGTS, BASIC CORPORATION LAW 101 (1979). An act not covered by the warrant or charter was ultra vires and as such was "void, illegal, and a nullity." H. HENN, HANDBOOK OF THE LAW OF CORPORATIONS AND OTHER BUSINESS ENTERPRISES $\$ 184$ (2d ed. 1970). For a rare example of the ultra vires remedy used to keep corporate funds out of the political arena, see McConnell v. Combination Mining \& Milling Co., 31 Mont. 563, 79 P. 248 (1905). See generally L. FRIEDMAN, A HISTORY OF AMERICAN LAW 453-54 (1973) (detailing the rise and fall of ultra vires doctrines). The state supreme court in Bellotti saw the Massachusetts statute as an attempt to guard against ultra vires acts of corporate managers. See infra p. 1649.

26. See First Nat'l Bank v. Bellotti, 435 U.S. 765, 778 (1978) (White, J., dissenting). Justice Rehnquist also declined to grant First Amendment protection to the political expression of business corporations. Like Justice White, he argued that corporations, created by the state and granted special privileges, are entitled to only those constitutional protections "incidental to [their] very existence" and implied by their charter. Liberty of political expression, Justice Rehnquist concluded, is not "necessary to effectuate the purposes for which States permit commercial corporations to exist." Id. at 82526 (Rehnquist, J., dissenting).

Justice Powell rejected a fiction-like analysis of the corporate person. He congratulated the Massachusetts court for rejecting appellant's argument that corporations, as creatures of the state, possess only those rights granted by the state. This "extreme position," the Justice explained, "cannot be reconciled with the many judicial decisions holding invalid under the Fourteenth Amendment, state laws that infringe on protected corporate speech." Id. at 778 n.14. 
those needs, it can be rewritten or even withdrawn. Thus, although the view historically known as the fiction theory has lost much of its persuasive power, the political implications of that view die hard: the corporation is a creature of the state and can be made to answer its maker.

\section{B. Contract Theory}

The view that incorporation is a privilege accorded by the sovereign came into growing disfavor in the nineteenth century amid charges of monopoly and corruption. ${ }^{27}$ As access to corporate status became a right of the many, ${ }^{28}$ the corporation came to be regarded progressively less as a creation of the sovereign and increasingly more as a product of contractual agreement. ${ }^{29}$ The resulting contract view of corporate personality interprets the corporate form as but a convenient summarizing device for the limited rights and duties of the private parties who contractually create

27. Exclusive franchises, it was generally believed, were never granted but for political or monetary consideration. J. HURST, supra note 25. Furthermore, an economy geared to expansion in space and productive capacity could not long tolerate the anti-competitive character of the monopolistic grants of privilege the fiction theory historically sanctioned. $M$. HORWITZ, THE TRANSFORMATION OF AMERICAN LAW, 1780-1860, at 108-39 (1977).

28. General legislative acts gradually replaced specific charters as the mode of incorporation, thus making the corporate form a more common mode of business enterprise. See L. FRIEDMAN, supra note 25 , at 447 "It was cheap and easy to incorporate under general laws-a few papers filed, a few forms and signatures; the privilege of incorporation lay open to whocver wanted it . . . "). In 1811, New York State enacted the first general incorporation law for certain kinds of manufacturing companies. By 1835, general incorporation statutes had been passed in several states. Dodd, American Business Association Law a Hundred Years Ago and Today, in 3 LAW: A CENTURY OF PROGRESS 254, 289 n.85 (A. Repply ed. 1937). General laws of incorporation at first contained severe restrictions on corporate size, lifespan, and scope of activities; permission to incorporate "for any lawful purpose" was not common before 1875. See Clark, The Four Stages of Capitalism: Refiections on Investment Management Treatises, 94 HARV. L. REV. 561, 562 n.4 (1981).

29. See Trustees of Dartmouth College v. Woodward, 17 U.S. (4 Wheat.) 518 (1819). The case involved an act of the New Hampshire legislature altering, without the consent of the corporation, the charter granted by the British Crown to the original trustees of Dartmouth College. In effect, the legislature converted the college into a state instrument by giving the governor of New Hampshire the right to expand the board of trustees and to fill all vacancies. Chief Justice Marshall declared that while the power of the state may be necessary to create and sustain a corporation, the corporation does not thereby become a public institution: "It is no more a state instrument than a natural person exercising the same powers would be." Id. at 636. Since the certificate of incorporation is a contract first between the state and the incorporators and secondly among the incorporators themselves, Dartmouth College is shielded from unreasonable state interference by the constitutional provisions securing contractual arrangements.

The language of Chief Justice Marshall's opinion in Dartmouth College often suggests a fiction theory of corporate personality: "[A] corporation is an artificial being, invisible, intangible, and existing only in contemplation of law. Being the mere creature of law, it possesses only those properties which the charter of its creation confers upon it, either expressly or as incidental to its very existence." Id. at 636. Chief Justice Marshall in fact subsequently came to regret this and other such descriptions of the corporate person. Louisville, C. \& C. R.R. Co. v. Letson, 43 U.S. (2 How.) 497, 555 (1844) (Wayne, J.); 1 W. FletcheR, CYCLOPEDIA OF THE LAW OF PRIVATE CORPORATIONS $§ 24$, at 99 n.37 (rev. perm. ed. 1975). Although strong protest greeted the Dartmouth decision, see L. FRIEDMAN, supra note 25 , at $174-75$, state courts had already started to draw the new distinction between public and private corporations. See M. HORWITZ, supra note 27, at 112-113. 
the corporation. ${ }^{30}$ The authority of the sovereign toward the corporation, the contract theorist concludes, is no greater and no less than its authority toward any other private agreement among contracting parties. ${ }^{31}$ This trend toward greater freedom of contract, however, could not assuage lingering doubts about the legitimacy of private centers of economic power, doubts given judicial expression in opinions based on peculiar amalgamations of contract and fiction theories. ${ }^{32}$

The state court's opinion in Bellotti reflected no such doubt, at least insofar as it came to legitimizing the state's power to regulate corporate expenditures in the political arena. Such regulation is "reasonably related

30. See V. MorawetZ, A Treatise ON The LAW of Private Corporations $\S 1$, at 2 (1882) ("IT]he existence of a corporation independently of its shareholders is a fiction; . . . the rights and duties of an incorporated association are in reality the rights and duties of the persons who compose it, and not of an imaginary being.").

31. As with the fiction view, there seem to be several conflicting versions of the contract theory in the literature. The formulation most widely held reduces the corporate person (or, as it is sometimes said, the corporate name) to a simple "contrivance" for referring summarily to the contractual rights and duties of the incorporators. French, supra note 1, at 209. Another formulation of the contract view asserts that these contractual bargains create an entity which is not reducible to the collective prerogatives and obligations of shareholders. See Pollock \& Maitland, Corporation and Person, in ANTHROPOLOGY AND EARLY LAW 303 (L. Krader ed. 1966) (corporation created through contract becomes indivisible unit comparable to human being).

As the term is used in this Note, the contract view accepts the ontological conclusion of the fiction theory that there is no extra-legal, corporate ens other than the collective powers and responsibilities of the incorporators, but rejects the political premise that the incorporator is really the sovereign or the state. Private parties, by adopting the corporate form, simply draw the attention of the judiciary to the fact that they have reached one kind of contractual agreement and not another. See R. WINTER, supra note 24 , at $1-3$. Those theories that reject a minimalist ontology will be treated as instances of realism. See infra pp. 1649-51.

The difference between the fiction and contract views is illustrated in Continental Tyre \& Rubber Co. v. Daimler Co., 84 L.J.K.B. (n.s.) 926 (1915). The plaintiff-corporation was chartered under English law; its directors were German nationals, residing in Germany; and all its shares but one were held by German citizens. The controversy turned on the question of whether the company was an English subject who could bring suit independently of its German directors and stockholders, thus avoiding the terms of the Enemy Trading Act. The court held that the corporation was "a different person altogether from the subscribers to the memorandum, or the shareholders on the register," id. at 937, and, therefore, could sue in an English court as a British subject. Lord Buckley, however, insisted on reducing the corporate form to the contracting parties who had created it. "The artificial legal entity has no independent power of motion," he declared. "It is moved by the corporators . . . [who are] German in fact, but British in form." Id. at 945 (Buckley, L. J., dissenting). See F. HaLLIS, supra note 3, at vi; Smith, Legal Personality, 37 YALE L.J. 283, 297 n.53 (1928).

32. Thus, in Bank of Augusta v. Earle, 38 U.S. (13 Pet.) 519 (1839), the Taney Court declared that a corporation was not a "citizen" within the meaning of the privileges and immunities clause of the United States Constitution. A corporation, therefore, could not as a matter of consitutional right do business in a state other than the one in which it has been incorporated. The Court also held, however, that states would be presumed, as a matter of comity, to have recognized the acts of other states, their fellow sovereigns. This dual holding is said to mirror "the tensions of mid-nineteenth century public policy toward the legitimacy of the corporation." J. HURST, supra note 25, at 64-65. On the one hand, the denial of the protection afforded by the privileges and immunities clause signifies that the rights of the corporation are not those of the incorporators and reflects the same distrust of private power inherent in the notion that the act of the sovereign fully circumscribes the powers of his creatures. On the other hand, the presumption of comity reflects legislative practices which accorded corporate status as a matter of statutory right to almost any businessman applying for it.

Subsequent decisions removed much of the substance of the Augusta decision insofar as it limited the rights of corporations to do business outside the state of incorporation. See infra note 35 . 
to a legitimate public purpose": the protection of shareholders against ultra vires acts of management. ${ }^{33}$ This notion that managerial authority is carefully circumscribed by a fiduciary duty to shareholders developed as the contract view came to dominate Anglo-American jurisprudence and declined in importance as that view lost its centrality. ${ }^{34}$

\section{Realism}

The final explanation of the corporate person is ontologically the most daring of the three views. The law does not create its own subjects, realism asserts; rather, it is forced to recognize the extra-legal existence of certain "persons"- some natural, others not. ${ }^{36}$

To the realist, a corporation is more than a legal fiction ${ }^{38}$ and more

33. First Nat'l Bank v. Attorney Gen., 371 Mass. 773, 794, 359 N.E.2d 1262, 1275 (1977), rev'd sub nom. First Nat'l Bank v. Bellotti, 435 U.S. 765 (1978). For a discussion of the ultra vires doctrine, see Brudney, supra note 4, at 243-52 (examining corporate political speech as ultra vires violation of management's duty not to act wastefully); see supra note 25 ; infra note 38 .

34. For a description of these fiduciary duties, see infra note 53.

35. The classical expression of this view is found in O. VON GIERKE, DIE GENOSSENSCHAFTSTHE. ORIE (1887). "Natural persons" should not be identified with physical persons. A natural person is as much a legal construct with implied rights and responsibilities as is an artificial person (like the corporation). Often large classes of physical persons-Jews, monks, serfs in medieval England, minors and mental incompetents in the United States-are not deemed natural persons by the law. $1 \mathrm{~F}$. POLLOCK \& F. MAITLAND, THE HISTORY OF ENGLISH LAW 461-75 (1898).

The realist understanding of the corporate person first came to prominence in American jurisprudence in the latter part of the nineteenth century as the Supreme Court rapidly expanded the number of constitutional protections afforded artificial persons against state regulation. In 1886, for example, even before arguments had been heard in the case, Justice Waite announced from the bench that:

The court does not wish to hear argument on the question whether the provision in the

Fourteenth Amendment to the Constitution, which forbids a State to deny any person within

its jurisdiction the equal protection of its laws, applies to these corporations. We are all of the opinion that it does.

Santa Clara County v. Southern Pac. R.R., 118 U.S. 394, 396 (1886). In subsequent decisions, the Court decided that corporations might seek protection of "liberty" (to transact business) and of "property" (against unreasonable state laws). Chicago, M. \& St. P. R. Co. v. Minnesota, 134 U.S. 418 (1890); Smith v. Ames, 169 U.S. 466 (1898). In so extending constitutional rights to corporate persons, the Court vitiated much of the force of the Augusta decision. See supra note 32 . States could still supervise the affairs of artificial persons, but only to the extent that they could constitutionally limit the activities of natural persons under the Fourteenth Amendment.

Charles and Mary Beard have made popular a "Conspiracy Theory of the Fourteenth Amendment," which alleges that the constitutional provision had been drafted so as surreptitiously to include corporations among its intended beneficiaries. THE RISE OF AMERIGAN CIVILIZATION 113 (1927). But see J. HURST, supra note 25, at 66-69 (attacking the Beards' argument); Graham, The Conspiracy Theory of the Fourteenth Amendment, 47 YALE L.J. 371 (1937) (same). If Santa Clara and the cases following it are explained as a change in the framework by which the judiciary understood the corporate person, there is no longer any need to explain this radical transformation in terms of a conspiracy theory.

Whether the product of conspiracy or not, this line of cases has made every act of state and local government that touches adversely the rights of corporate persons subject to review by the Supreme Court. For a general review of the Court's handling of such cases, see Wheeling Steel Corp. v. Glander, 337 U.S. 562, 576 (1949) (Douglas, J., dissenting); Connecticut Gen. Life Ins. Co. v. Johnson, 303 U.S. 77, 83 (1938) (Black, J., dissenting). Both Justices conclude that Santa Clara should be overruled.

36. To get a taste of this "more," consider Berle's account of what would happen if a large 
than the sum of shareholder rights and duties. ${ }^{37}$ The business corporation is a complex mode of productive organization with a logic of its own. Corporate managers are often left with few options as they try to satisfy the conflicting pressures of investors and the state, while protecting the organization's capacity to respond to market opportunities. ${ }^{38}$ Sound busi-

corporation were suddenly shorn of its legal existence by an act of the state:

Clearly it is not the law, with its fiction of juristic personality, that supplies the life blood and beating heart of those vast mechanisms. If the law, acting through some instrumentality, declared that they did not exist, the entities would be found to be not fictitious, but factual . . . In vain would some lawyer complain that the directors could no longer fix policy, or the president give orders . . . . The huge machine would keep right on rolling. This is the essence of an institution, and not of a legalistic creation.

A. BERLE, THE TWENTIETH CENTURY CAPITALIST REVOLUTION 18-19 (1954).

In general, realism asserts that the corporation-at least the modern, business corporation-is not a creature of the state, even though the laws that govern it are. The corporation is "the first new autonomous institution that has emerged in Western society since the collapse of the medieval order .... It is the local self-government of modern society, the logical successor to manor, village and town." Drucker, The Meaning of Mass Production, 57 COMMONWEAL 547 (1953). See generally C. LINDBLOM, POLITICS AND MARKETS (1977) (describing the effect of corporate economies on democratic processes).

37. J.J. McCaskill Co. v. United States, 216 U.S. 504, 514 (1910) ("Undoubtedly a corporation is, in law, a person or entity distinct from its stockholders and officers."). Cf. V. MORAWETZ, supra note $30, \S 1$, at 2 ("[T]he existence of a corporation independently of its shareholders is a fiction."). The corporation, moreover, does not act or hold property as an agent of the stockholders. $1 \mathrm{~W}$. FLETCHER, supra note $29, \S 30$, at 130.

The attack on the nineteenth century assumption that equity interests are the defining concern of the corporate person has taken many forms. The first assault was made against the notion that shareholders effectively control the modern corporation. See A. BERLE \& G. MEANS, THE MODERN CORPORATION AND PRIVATE PROPERTY 346-47 (1932) (distinguishing "passive property" or the rights of ownership retained by equity and "active property" or the power entrusted to management to use economic resources).

Equity's loss of power over business operations has been accompanied by a move in the law from a rule of unanimous shareholder consent for significant alterations of the corporate structure to a simple majority rule, further strengthening management's control over the corporation. See Carney, Fundamental Corporate Changes, Minority Shareholders and Business Purposes, 1980 AM. B. FoUND. RESEARCH J. 69. For additional changes in corporate charters diminishing equity power over corporate affairs, see J. COLEMAN, POWER AND THE STRUCTURE OF SOCIETY 44-50 (1974). For an analysis of the "de facto autonomy" these developments have brought to management, see Rostow, To Whom and for What Ends Is Corporate Management Responsible?, in THE CORPORATION IN MODERN SOCIETY 46 (E. Mason ed. 1959).

38. These managers, according to the realist, have fiduciary duties to the corporate person, which are distinct from and often in conflict with their duties to shareholders. See J. COLEMAN, supra note 37 , at 49 . Increased return on equity is not an exclusive goal, but merely one of several constraints (like wages and federal guidelines) which must be taken into account by those who control the corporation. See Mason, The Apologetics of Mangerialism, 31 J. Bus. 1, 3 (1958) (noting views of chairman of Standard Oil that managers of corporation must conduct its affairs "in such a way as to maintain an equitable and working balance among the claims of the various directly interested groups-stockholders, employees, customers, and the public at large"); A.P. Smith Mfg. Co. v. Barlow, 13 N.J. 145, 147, 98 A.2d 581, 583 (1953) (citing views of Standard Oil chairman).

The classic debate as to whom the duties of corporate management ultimately run was conducted by Professors Berle and Dodd some fifty years ago. Berle began with a thesis compatible with the older contract view: corporate powers are held in trust, "necessarily and at all times exercisable only for the ratable benefit of all the stockholders as their interest appears." Berle, Corporate Powers as Powers in Trust, 44 HARV. L. REV. 1049, 1049 (1931). Professor Dodd replied in a realist vein: directors should be legally understood as trustees for the enterprise and not merely as attorneys for stockholders. Dodd, For Whom Are Corporate Managers Trustees?, 45 HARV. L. REv. 1145 (1932). Berle finally accepted Dodd's initial position in A. BERLE, THE TWENTIETH CENTURY CAPITALIST REVOLUTION 
ness judgment is all the law can reasonably demand of those who must respond to the needs of complex economic institutions within a hostile environment. ${ }^{39}$

In reinforcing the power of management over the corporate fisc, the Supreme Court's majority opinion in Bellotti reflects a realist understanding of the modern, business corporation as something other than the natural persons who constitute it. In arguing that the Massachusetts statute would limit the stock of information available to the public, ${ }^{10}$ Justice Powell cannot be referring to the purely personal views of corporate management, for corporate officers would still be free under the law to express themselves in their private capacities. ${ }^{11}$ The Justice must be alarmed, then, by the threat the Massachusetts law poses to the views of the corporation itself, views which management is under a fiduciary obligation to express when it speaks in its corporate capacity or when it allocates corporate funds to influence a political question.

The notion that soulless, inarticulate corporations could even hold a political view, let alone insist on the right to express it, would be incomprehensible to the scholastic philosophers and the classical economists who provided the conceptual ground for earlier explanations of corporate personality. The organizations they knew as corporations, however, would be deficient in many respects when compared with this modern form of production. ${ }^{42}$

(1954). The view that the duties of corporate managers go beyond maximizing shareholder profit has been attacked as "a fundamentally subversive doctrine." M. FRIEDMAN, CAPITALISM AND FREEDOM 133-36 (1962).

39. Under the business judgment rule, directors are not liable for honest errors of judgment, "even though the errors may be so gross that they may demonstrate the unfitness of the directors to manage the corporate affairs." 3A W. FLETCHER, supra note $29, \S 1039$. In effect the business judgment rule allows corporate directors uninhibited discretion, absent self-dealing, bad faith, or lack of due care. The rule has come to replace the moribund notion of ultra vires, which limited corporate activity to those privileges specifically granted by the sovereign in the charter of incorporation. See supra notes 25-26. Under the realist approach, an ultra vires act is not illegal unless it is a public wrong. $H$. HENN, supra note $25, \S 184$. For a brief account of the replacement of ultra vires by the business judgment rule, see L. FRIEDMAN, supra note 25 , at 453-54.

40. First Nat'l Bank v. Bellotti, 435 U.S. 765, 783 (1978).

41. As one brief in Belloti stated,

If there is speech involved here, it must be the speech of management. But corporate managers are free to speak as they wish, and to spend money to promote their beliefs and ideas. What they claim is that their speech is abridged by their inability to use their employer's treasury to promote political viewpoints.

Brief for Appellee at 18, First Nat'l Bank v. Bellotti, 435 U.S. 765 (1978). Justice Powell's concern for those voters "interested in hearing appellants' views" on referendum issues, Bellotti, 435 U.S. at $782 \mathrm{n} .18$ (emphasis added), must be understood in terms of the frequent references to "the corporate identity of the speaker." See supra note 8.

42. See Rostow, supra note 37 , at 50 (comparing modern corporations to "puny institutions" of cighteenth and nineteenth century). 


\section{A New Model for the Corporate Person}

Twentieth century developments in corporate economies suggest a way of looking at the corporate person that increasingly informs contemporary, economic and sociological analysis of corporations but has not yet been raised to the level of legal methodology. This Note assumes those developments in suggesting a legal model for the corporation with two foci: first, the notion that a corporation, like all complex organizations, should be understood not as an object, but as a set of role relations, and, second, the observation that in any particular relation, the corporation, unlike a natural person, must be represented by an agent.

In contrast with earlier views of corporate personality, the proposed model does not reduce the corporation to a single set of interests and, consequently, does not by itself define the rights and duties of the corporate person. Instead, it translates questions about the constitutional rights of corporations into questions about the powers and duties of those agents who represent the corporate person.

\section{A. The Corporation as a Set of Role Relations}

Each of the views of the corporate person heretofore dominant reduces that person to the interests of a single party, implicitly rendering the interests of all other parties illegitimate or at least of lesser legal significance. Thus, the legal rights and duties of corporations have been determined principally, and at times solely, by the interests of the sovereign, ${ }^{43}$ the interests of shareholders, ${ }^{44}$ and the interests of formal organizations. ${ }^{45}$

This reduction of the juristic essence of the corporate person to a single set of interests makes parsing corporate powers a simple and even mechanical task. ${ }^{48}$ The simplicity of this approach, however, masks the fact that corporations are complex totalities of role relations affecting groups with varied and multiple interests. To ignore or to delegitimize all but one set of these interests is to misunderstand the nature of the entity whose legal personality requires definition. A more adequate view would legitimize an entire range of interests considered of secondary legal importance by one or another of the earlier views. ${ }^{47}$

\footnotetext{
43. See supra pp. 1645-47.

44. See supra pp. 1647-49.

45. See supra pp. 1649-51.

46. See, e.g., Hale v. Henkel, 201 U.S. 43, 74-75 (1906) (corporate powers reduce to privileges granted by the state and codified in the charter); San Diego Gas Co. v. Frame, 137 Cal. 441, 447, 70 P. 295, 297 (1902) (corporate "rights and duties are in reality the rights and duties of persons who compose it"); 711 Kings Highway Corp. v. F.I.M.'s Marine Repair Serv., Inc., 51 Misc. 2d 373, 273 N.Y.S.2d 299 (Sup. Ct. 1966) (validating ultra vires acts of corporate agents in pursuit of business interest).

47. The notion of legitimizing interests formally unrecognized by earlier legal paradigms finds an
} 
The development of the corporate form in the twentieth century illustrates why the corporation should be viewed as a set of role relations. ${ }^{48}$ The century began with the fabled split of corporate ownership from control; legal norms to regulate professional business managers became essential for the protection and facilitation of public investment. ${ }^{49}$ These norms are but one instance in a long series of legal responses to the appearance of new institutional actors. More recently, the law has come to regulate portfolio managers, indenture trustees, institutional investors, and other financial intermediaries standing between corporate wealth and the beneficial owners. ${ }^{\text {so }}$

The conclusion to be drawn from these developments is that a form of productive organization, like the corporation, cannot be properly understood as a monolith; a corporation is rather a composite of role relations governing the conduct of various sets of individuals (managers, directors, financial planners) toward other sets of individuals both within the corporation and without (employees, consumers, shareholders, creditors, other agents). To look for the legal essence of the corporation in any one of these relations or in any one of the parties so related is to look for unity where there is irreducible diversity.

\section{B. The Corporate Agent}

Unlike natural persons, a corporation can act only through those who

analogue in the arguments recently advanced for attributing jural status to natural objects in environmental litigation. Under this approach, natural objects can assert (through guardians) their own right not to be despoiled. See C. STONE, SHOULd TREes HAVE STANDING? (1974). Stone recognizes the parallel between his proposal and the earlier personification of the corporation:

[T]o urge a court that an endangered river is "a person". . . will call for lawyers as bold and imaginative as those who convinced the Supreme Court that a railroad corporation was a "person" under the fourteenth amendment, a constitutional provision theretofore generally Id. at 18 .

thought of as designed to secure the rights of freedmen.

48. The terms "role" and "role relation" have become commonplace in contemporary social science and are used to describe the situation in which particular human beings have significance by virtue of the position they hold, rather than by virtue of their individual identities. See, e.g., E. GOFFMANN, THE PRESENTATION OF SELF IN EVERYDAY LIFE 1-16 (1973) (describing daily behavior as system of dramaturgical roles); M. WEBER, LAW IN ECONOMY AND SOCIETY 334-37 (M. Rheinstein ed. 1954) (describing bureaucracy as a system of role-defined positions). In the corporate context, the function of persons is to carry out activities appropriate to their roles as employees, directors, or managers. Thus, corporate officers do not hold "active property rights" in business assets as persons. See A. BERLE \& G. MEANS, supra, note 37, at 346-47. Those rights attach to positions, not to the individuals who hold those positions.

49. See supra note 37 .

50. See Clark, supra note 28 , at 564-65 (detailing the rise of financial intermediaries). The legal response to new corporate actors often involves major legislation. See, e.g., Securities Act of 1933, 15 U.S.C. $\$ \S 77 a-77 e$ (1976) (regulating public offerings in interstate commerce); Trust Indenture Act of 1939, 15 U.S.C. $\$ \S 77 \mathrm{aaa}-77 \mathrm{bbbb}$ (1976) (protecting indenture holders from breaches of fiduciary duty by trustees); Investment Advisors Act of 1940, 15 U.S.C. $\S \S 80 \mathrm{~b}-1$ to $80 \mathrm{~b}-21$ (1976) (protecting against malpractice by securities advisors). 
represent it, that is, only through agents. ${ }^{\$ 1}$ Thus, any legal description of the rights and duties of a corporation is actually a description of the powers and duties of corporate agents (acting not in their capacities as natural persons but as embodiments of certain roles). Through its board of directors, the corporation may stand opposed to the state as a legally recognized entity protected from the arbitrary seizure of property. Through its managers, it may stand as a fiduciary for capital investment or as a goodfaith participant in employment negotiations. Through its agents, it may stand in any number of legal relations to any number of parties.

The law regulates these relations by specifying the traditional duties agents formally owe principals. ${ }^{\mathbf{6 2}}$ These duties, while expressed as obligations toward the corporate person, actually specify the powers and obligations of agents with regard to the groups before whom they stand as corporate representatives. ${ }^{6 s}$ Statements about the rights and duties of a

51. 2 W. FLETCHER, supra note 39 , at $\S 437$ ("In the nature of things, a corporation . . . cannot act at all except through persons representing it.") (emphasis added). The relation known as agency is based on a fiduciary relation between principal and agent whereby the latter is given the power to bind the former legally. RESTATEMENT (SECOND) OF AGENCY §§ 1-8 (1957); see also C. STONE, WHERE THE LAW ENDS 14-15 (1975) (describing the minimal role agents played in early business corporations and giving short account of their rise to prominence in modern corporations).

52. See, e.g., 15 U.S.C. $\$ 77 f$ (1976) (specifying duties of corporate officers in filing securities registration statements); 15 U.S.C. $\$ 77 \mathrm{jjj}$ (1976) (specifying duty of indenture trustees to avoid conflicts of interests); 15 U.S.C. $\$ 80 \mathrm{~b}-5$ (1976) (specifying duties of investment advisors entering into investment advisory contracts).

Corporate agents traditionally owe their principal the duty of loyalty, a duty to give notice, and a duty of care. See H. HENN, supra note 25 , at $\$ \S 235-242$. These duties are legally empty until given content by statute or judicial decision.

53. Any statement about a duty of an agent to a corporate principal is actually (though only implicitly) a statement about the agent's duty to some other party or parties. This can be illustrated by reference to the tripartite division of duties traditionally attributed to the (corporate) agent. See supra note 52. For example, in Perlman v. Feldmann, 219 F.2d 173 (2d Cir. 1955), a classic case of violation of the duty of loyalty, minority shareholders successfully asserted in a derivative action the corporate right to compel restitution of illegal gains accruing from the sale of controlling interest in the corporation. The court held that both as a director and as the dominant shareholder, the defendant stood in a fiduciary relationship to the corporation, a relationship he violated by not offering minority shareholders the chance to participate in a "corporate opportunity." 219 F.2d at 175-76; see Andrews, The Shareholder's Right to Equal Opportunity in the Sale of Shares, 78 HARV. L. REV. 505 (1965) (interpreting Perlman as imposing on controlling stockholder a duty to minority stockholders). Thus, the duty of loyalty legally owed to the corporation reduces in this instance to a specification of how majority shareholders/directors must treat other shareholders. The same kind of reduction can be made with regard to the duty of care. See Francis v. United Jersey Bank, 162 N.J. Super. 355, 392 A.2d 1233 (1978) (director violated duty of care to bankrupt corporation by negligently reducing value of assets distributable to creditors). In this case, the duty, which is said legally to run to the corporation, is in fact specified as a duty to creditors. The duty to give notice can be similarly analyzed. See In re Investors Management, Securities Exchange Act Release No. 9267, [1971] FED. SEC. L. REP. (CCH) II 78,163 (July 29, 1971) (an outsider, a "tippee," far removed from the original leak of material information and having no ties to the corporation, breached duty to corporation by not revealing privileged information to investment community).

The corporate name is obviously a convenient summarizing device, see supra note 31 , and to this extent the contract view of the corporate person is correct. The name, however, summarizes more than the responsibilities and rights of subscribers vis-à-vis the state and the public. The rights and duties of the corporation signify the powers and responsibilities of a potential host of corporate actors or agents toward manifold and diverse groups. 
corporation must, then, be translated into an equivalent set of implied statements about the powers and responsibilities of corporate agents with regard to the various parties they confront. The juristic person we call the corporation is the totality of these agential powers and duties.

\section{A New Mode of Legal Analysis: The Deconstitutionalization of Cor- porate Rights}

Properly seen, corporate rights derive entirely from judgments about the relative rights of the parties affected by corporate acts. A judicial decision to grant a constitutional right to a corporation is, therefore, more accurately interpreted as a legal instruction to corporate agents always to favor the interests of certain groups over those of other groups, an instruction which derives from a judgment-constitutional or otherwise-that the interests of those groups should be favored by the law. Thus, corporate rights do not flow directly from corporate personality, but only indirectly from the legally cognizable interests subsumed under the corporate form.

If Bellotti is reexamined under the proposed model, one must conclude that Justice White is correct: In asking whether corporations can contribute to referendum campaigns, we are really asking about management's right to allocate the corporate fisc, a question that cannot be answered without first determining the nature of mangement's duty to shareholders, creditors, and the Massachusetts polity. ${ }^{54}$ Seen in this light, Bellotti is not properly a First Amendment controversy. On its surface, the case appears to hinge on the range of rights the Constitution affords corporate speakers; on a deeper level, the case calls for a legal ordering of the interests of other parties.

Bellotti does not in itself further the values protected by the First Amendment. Instead, it constitutionally legitimizes management's discretionary power to use corporate funds in expressing the political views of those who run the corporation. ${ }^{55}$ All such ascriptions of constitutional

54. First Nat'l Bank v. Bellotti, 435 U.S. 765, 803 (1978) (White, J., dissenting). Even if shareholders were unanimous in their desire to promote a particular political position and so instructed corporate management, the corporation itself would not thereby acquire a constitutional right to use its assets in the public arena. The state allows investors to use a vehicle particularly adapted to the expansion of capital. The fruit of that expansion, however, is the property of the corporation and not of the shareholders. W. FLETCHER, supra note $29, \S 31$, at 132 . The legal rights to corporate capital cannot be reduced to the constitutional rights of equity investors, nor can the powers and duties of management be reduced to the interests of shareholders. See supra note 37. But cf. Bellotti, 435 U.S. at 786-95 (statute is overbroad in banning political contributions even when shareholders unanimously agree with the expenditure); Brudney, supra note 4, at 252-65 (discussing stockholder consent to corporate political speech).

55. See O'Kelley, supra note 4, at 1373, 1382. Of the many commentators on the Bellotti decision, see supra note 4, O'Kelley is unique in grounding his analysis in something akin to a theory of corporate personality. He finds at work in the decisions attributing constitutional rights to corporations two rationales. The first, "the Field rationale," asserts that the constitutional rights of a business 
rights ${ }^{56}$ to corporate bodies should be analyzed in terms of the powers and duties such judgments confer on corporate agents. ${ }^{57}$ The fact that we grant corporate persons Fourteenth Amendment protections against the arbitrary seizure of property, for example, need not commit us to a grant of First Amendment rights. ${ }^{88}$ Properly analyzed, these two judgments reveal

corporation in the protection of its property are coextensive with the rights its shareholders would enjoy had they conducted their business in an unincorporated form. Id. at 1356. The Field rationale, in other words, is a version of the contract theory, restricted to corporate property rights. O'Kelley also refers to the "associational rationale," a judicial rule by which individuals with common aims may express their shared political views through the medium of a corporation. Id. at 1365 . The question in Bellotti, as O'Kelley sees it, is the extent to which these rationales sanction the political expression of a business corporation. O'Kelley finds the Massachusetts statute void on its face because it prohibits the expenditures of a corporation sole whose First Amendment rights, under the Field rationale, would be coextensive with those of the single shareholder. Id. at 1369 . He concludes that it is a "category-mistake" to talk of large, publicly held corporations as capable of speech, since expression can be generated only by natural persons. In this he is undoubtedly correct, but he fails to realize that the same category-mistake is made in speaking about the corporation's doing anything. Corporations can only act through agents whose powers and duties have been determined by the multiple legal paradigms for corporate personality.

56. See supra p. 1644.

57. For example, in Trustees of Dartmouth College v. Woodward, 17 U.S. (4 Wheat.) 518 (1819), the Court ordered a corporate agent, Woodward (Dartmouth's secretary/treasurer), to favor one group over another, that is, to return the corporate seal to the original trustees rather than give it to the new board appointed by the governor. See supra note 29. In treating the privileges conferred on the corporation by charter as contractual rights of the original incorporators, the Court radically restricted the state's capacity to regulate that which it had created, thus raising an "impregnable barrier" around the "literary, charitable, religious, and commercial institutions of the country." $2 \mathrm{~J}$. STORY, SUPRA note 21 , at $\$ 1395$. This barrier has as its foundation the Court's decision to attribute to the corporate person a constitutional right held by the incorporators. The immediate point is not that this decision or any other decision discussed below has been incorrectly decided, but that these decisions instruct corporate agents (and give them the legal capacity) to favor the interests of one set of people over the interests of another, in this case the putative interests of the original Dartmouth donors (then long deceased) over the interests of current legislative majorities.

A different balance was struck in Bank of Augusta v. Earle, 38 U.S. (13 Pet.) 519 (1839). See supra note 32. In rejecting the argument that the rights of the corporate body are coextensive with those of the incorporators, the Taney Court implicitly rejected the idea that corporate agents can assert the full rights of incorporators as the rights of the corporation. The Court thus returned to state legislatures partial "control over the extent of corporate franchises proper to be granted." 38 U.S. at 586. In denying corporations the constitutional privileges and immunities accorded citizens, the Court denied corporate agents the capacity to recover by right on bills of exchange in state courts. The effect is to elevate state power over the interests of investment capital, a balance radically altered by subsequent decisions. See supra note 35.

In Hale v. Henkel, 201 U.S. 43 (1906), the Court rejected, on the basis of a fiction-like analysis, the argument that the corporation's privilege against self-incrimination would be violated if a corporate officer testified before a grand jury or complied with a subpoena for the production of corporate records. Id. at 74-75. Justice Brown went on to say in dictum, however, that corporations, under the Fourth Amendment, are entitled to immunity against unreasonable searches and seizures. Having noted that "[c]orporations are a necessary feature of modern business activity," the Justice proceeded to ground this grant of constitutional right not in the interests of the sovereign or in those of shareholders but in the functional needs of the modern mode of production. 201 U.S. at 77. Cf. Wilson v. United States, 221 U.S. 361, 376 (1911) (adopting Justice Brown's analysis). This realist approach gives corporate agents like Hale the legal capacity to block governmental requests for information that disrupt the normal flow of business. The effect is to favor management's interests in running the business without interference over the interests of the government and many investors in procuring information about corporate operations. The mode by which these interests are ordered is the grant of a constitutional right to the corporate person.

58. The decision to grant business corporations Fourteenth Amendment protection against the 
policy decisons about different groups (shareholders, management) asserting different rights (protection of investment, control of the fisc) in different realms (the market, the political sphere).

\section{Toward a Unified Theory of Corporate Rights}

Grounding corporate constitutional rights in theories that reduce corporate personality to one or another set of interests necessarily leads to an inconsistent patchwork of constitutional law. Before unity can be brought to this patchwork, the multiple interests the corporation comprises must be recognized and thus legitimated, a step taken in translating assertions about corporations into assertions about the legal relation of corporate agents to other parties. Such translation, however, does not in itself suffice to specify the substantive rights of those parties. ${ }^{58}$ Thus, a unified theory of corporate rights also requires a scheme to order the possibly conflicting interests of those groups whose interrelation constitutes the corporate whole. ${ }^{60}$

seizure of property carries with it as little implication of corporate First Amendment freedoms as does the decision to limit shareholder liability to the value of investment. Each decision involves a political judgment best understood in terms of the implicit ascription of powers and duties to agents. The conferral of property rights on corporations involves a judgment as to the relative priority of the interests of various groups, a notion implicit in the post-Bellotti suggestion that states regulate the speech of utilities by defining the billing envelope as the property of rate-payers rather than as the property of the utilities. Consolidated Edison Co. v. Public Serv. Comm'n, 447 U.S. 530, 556 (1980) (Blackmun, J., dissenting) ("If, under state law, the envelope belongs to the customers, I don't see how restricting the utility from using it [to carry political messages] could possibly be held to deprive the utility of its rights."). In questioning the ascription of First Amendment rights to business corporations, the proposed model does not restrict the speech of corporate officers or shareholders. They remain free to express themselves in their private capacities or even to form incorporated associations to futher their political aims. See NAACP v. Button, 371 U.S. 415 (1963) (corporation formed expressly to promote the political views of its members can assert the First Amendment rights of its members).

59. The proposed model does have normative significance, however. For example, in addition to legitimizing interests excluded by earlier paradigms, see supra p. 1652, the model casts doubt on the legitimacy of finding a corporation guilty of a crime even though its agents have satisfied all relevant legal duties. See United States v. Hilton Hotels Corp., 467 F.2d 1000 (9th Cir. 1972) (acquittal of agent in prosecution under Sherman Act does not preclude convicting corporation of participation in criminal conspiracy), cert. denied, 409 U.S. 1125 (1973). Courts generally permit such inconsistent verdicts to stand, though not without complaint. See United States v. General Motors Corp., 121 F.2d 376, 411 (7th Cir.) ("We cannot understand how the jury could have acquitted all of the individual defendants. As a matter of logic, reconciliation between the verdict of guilt and verdict of acquittal is impossible."), cert. denied, 314 U.S. 613 (1941). Aside from offenses involving strict liability, the imposition of sanctions on a corporation whose agents have satisfied all duties running to the corporation must be treated as a legal nullity if the legal rights and responsibilities of the corporation are understood as powers and duties of corporate agents. Under the proposed view, there is no meaningful way to speak of corporate responsibility without implying an agential duty. See supra note 53. For a realist theory ascribing fault to a corporation independent of the fault of its agents, see French, supra note 1 , at $210-11$.

60. Each of the earlier views of the corporate person can be associated with a particular political and social philosophy which provides ordering principles. The original fiction theory, with its emphasis on the sovereign or monarch, requires a theory of absolute authority. See 2 T. HOBBES, LEVIATHAN $\S 14$ (Paris 1651) (describing rights of sovereign). The contract theory presupposes a view of 
By refusing to reify any one element in a web of social relations as the corporation, the suggested view allows one to appreciate the partial truth in each of the earlier views, thus providing a starting point for designing an ordering scheme. The virtue of realism, for instance, lies in its recognition of the consequences of organizing productive capacity around a certain economic form. The legally defined, institutional roles that constitute this mode of production specify the rights and duties of powerful agents and thus do affect the general social order. The demands these organizational actors make must be examined in terms of their effect on investment decisions, for the truth underlying the contract theory cannot be ignored: in our economy, corporations are usually privately financed. An efficient investment market, however, is but one of several goals our legal system might promote. Loosen the fiction theory from its absolutist moorings and we find a bare, political message: society should not lose control over that which it creates.

The truths offered by these theories are partial in that each describes as definitive but one of the many relations which constitute the corporate totality. A more adequate account of the corporation as a juristic person would capture that entity in its diversity by focusing on the varied legal roles defining the relation of corporate agents to the many parties those corporations affect.

\section{Conclusion}

Though there may be good reason to accord legal standing to the form used to organize society's productive capacity, basic decisions about social life should not be made (without further analysis) in terms of the rights of corporate persons. Those rights must be translated into statements about multi-polar relations among corporate agents, the affected parties, and society as whole. To do otherwise is to treat but one set of relations as definitive and all others as illegitimate or at least subordinate. Such a mistaken view cannot do justice to the complex organizations we call corporations nor bring justice to those affected by those organizations.

society in which human interaction can for the most part be regulated by private agreement. See $\mathrm{H}$. MAINE, ANGIENT LAW 99-100 (1917) (describing development of contract as governing principle in "progressive societies"). Realism is more difficult to place in a philosophical tradition, perhaps because, of the three views, it is peculiarly American and eclectic. It has obvious roots in neo-Hegelian visions of the corporate state current at the turn of the century, but it is laced through and through with American pragmatism. See J. DEWEY, RECONSTRUCTION IN PHILOSOPHY 187-213 (1920) (describing effect of pragmatism on social philosophy); G. HEGEL, PHILOSOPHY OF RIGHT $\$ \S 152-154$ (T. Knox trans. 1967) (analyzing corporation as transitional "moment" between civil society and the state); see also J. HABERMAS, LEGITIMATION CRISIS (T. McCarthy trans. 1975) (discussing breakdown of traditional social theories). 